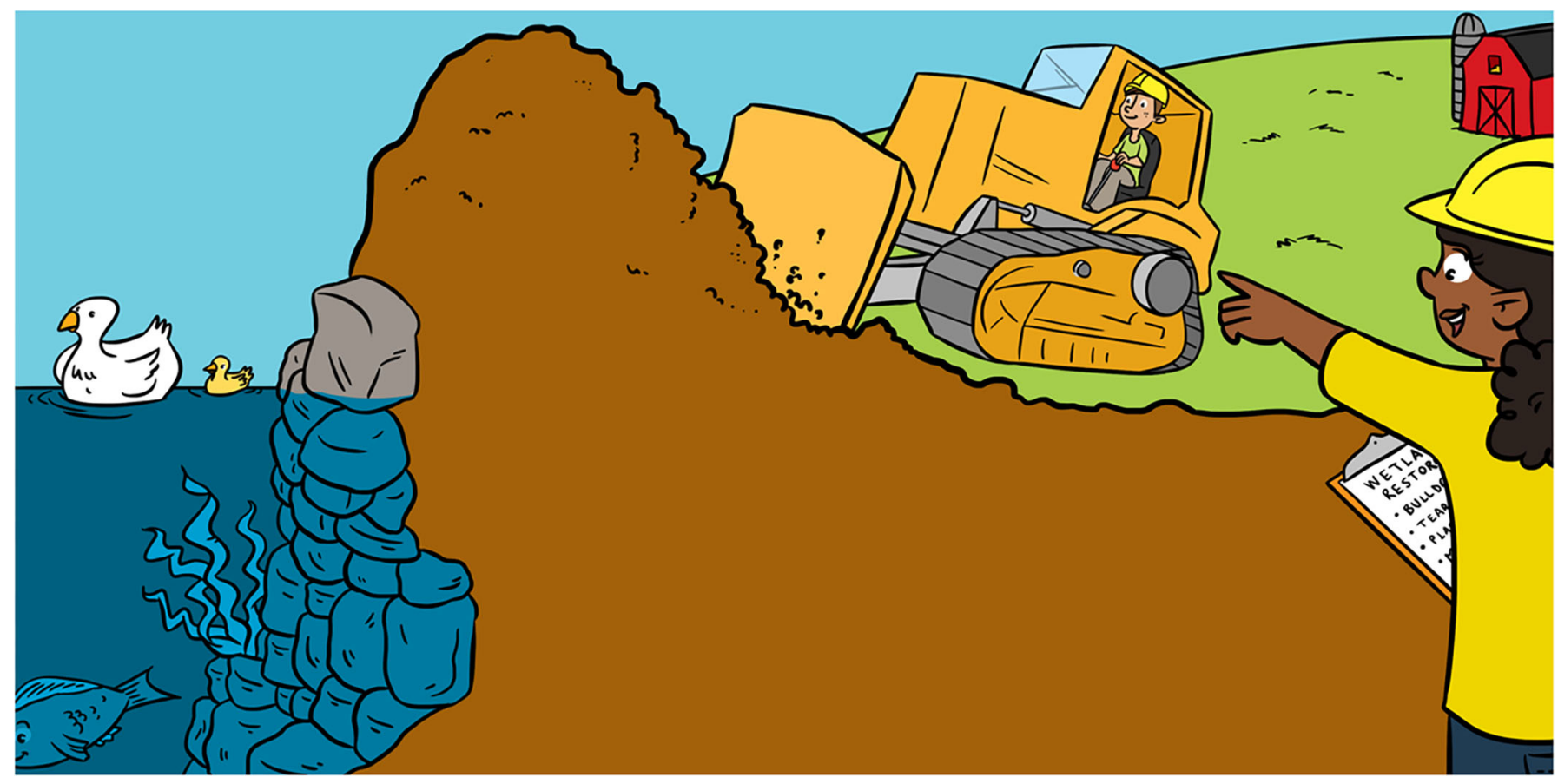

\title{
MARSH MADNESS: RESTORING TIDAL WETLANDS IN OUR ESTUARIES
}

\section{Stacy Sherman ${ }^{1 *}$ and Rosemary Hartman ${ }^{2}$}

${ }^{1}$ California Department of Fish and Wildlife, Stockton, CA, United States

${ }^{2}$ California Department of Water Resources, West Sacramento, CA, United States

YOUNG REVIEWER:

ANUSHA

AGE: 9
Just like people, fish need a safe place to find food and grow up. For fish that travel between fresh water and the ocean, tidal wetlands are a perfect neighborhood, with lots of habitat and food. Tidal wetlands are areas of shallow water where tides from the ocean cover the land with water every day. Besides providing a home for fish and water-loving plants, tidal wetlands also help protect people and their property from natural disasters like storms, and from sea-level rise. People have not always understood the value of wetlands, so billions of acres of them have been filled to farm or build on. In the San Francisco Estuary, more than $90 \%$ of wetlands were converted to other uses in $<150$ years! People now understand why wetlands are important, so protecting and restoring wetlands is a top priority. 
Figure 1

Tidal wetlands are home to water-loving plants and many animals, such as water birds, baby salmon, and the invertebrates they eat. At high tide, the wetland is mostly under water, but at low tide, water is just left in the deeper spots. Water coming out of the wetland with the tide can carry food to fish that do not live in the wetland. Invasive species, such as water weeds, clams, and Largemouth Bass, can also live in or near wetlands.

\section{ESTUARY}

A partly enclosed area on the coast where freshwater from rivers mixes with salt water from the ocean. Some estuaries have tidal wetlands within them.

\section{TIDAL WETLAND}

Land in an estuary or on the coast that is only covered with water when the tide is high. Special plants grow there.

\section{Wetland Function}

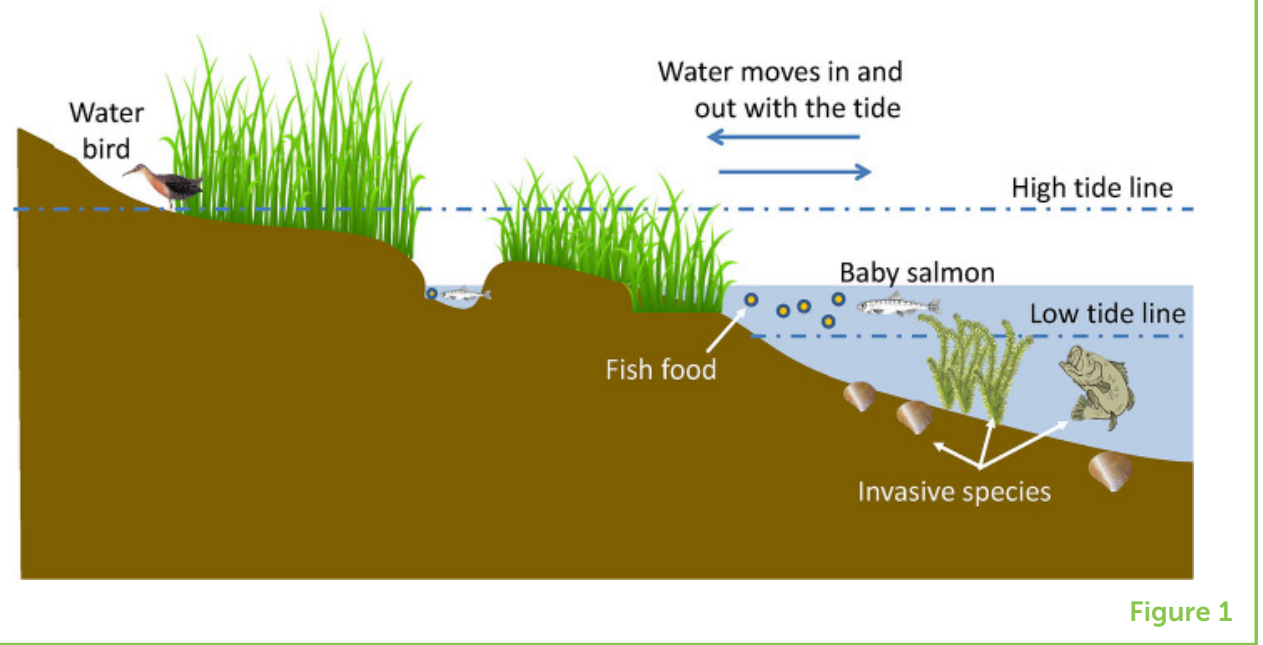

\section{TIDAL WETLANDS ARE IMPORTANT FOR FISH AND PEOPLE}

Just like you, a young fish needs a safe home where it can grow up, and that home needs a fully stocked refrigerator full of tasty, healthy food. Tidal wetlands often are...or were...that home. In estuaries all over the world, including the San Francisco Estuary, large areas of wetlands have been dried out by people so that they can build or farm on the land. Fortunately, we are restoring wetlands to provide a good home for young fish again.

Estuaries? Tidal wetlands? What exactly are these places? Estuaries are areas where freshwater from rivers meets the salt water from the oceans. Estuaries can be quite large and include many types of places where animals and plants live. Estuaries can have deep water, shallow water, narrow channels, and big areas of open water. Many estuaries include Tidal wetlands. They are shallow areas full of water-loving plants, such as reeds, cattails, and sedges [1]. Water goes into and out of tidal wetlands with the tide, so the land is mostly underwater at high tide, but water is only left in deep spots between the plants at low tide. Many fish depend on tidal wetlands. The plants slow the water down, so that tidal wetlands act like rest areas for fish tired of swimming in fast water. This is especially important for young salmon that are swimming all the way to the ocean from the rivers where they were born. Plants also provide places for young fish to hide from bigger fish that might eat them, and they support lots of invertebrates, including insects and shrimp that fish love to eat. When the tide moves into and out of a tidal wetland, it moves some invertebrates from the wetland to parts of the estuary where the water is deeper [2]. This movement brings food to other fish that do not live in the shallow wetland (Figure 1). Since many humans love to eat fish (especially salmon!), people also benefit from tidal wetlands. 


\section{LEVEE}

A physical structure, mostly made of dirt, that was built to keep rivers or bays from flooding a piece of land.

\section{INVASIVE SPECIES}

Plants or animals from another part of the world that are brought into a new place, get too abundant, and are bad for the species that were already there.
In addition to providing us with fish, tidal wetlands help people in other ways, too. The spongy soils in tidal wetlands act as natural filters, cleaning pollution from the water. Many people get their drinking water from estuaries, so cleaner is better! Tidal wetlands can protect people's coastal houses from floods and storms by absorbing energy and water. The plants that grow in wetlands also take carbon dioxide out of the atmosphere, slowing down climate change [1]. Other animals also benefit from tidal wetlands: otters, snakes, and lots of birds! In fact, the tidal wetlands of the San Francisco Estuary, where we work, are an important part of the Pacific Flyway-the route that many ducks and geese take to travel to and from their winter homes in the south and their summer homes in the north. Birds need to stop and take a rest and have some snacks, too!

\section{MANY TIDAL WETLANDS ARE IN DANGER}

People have not always understood why tidal wetlands are so important. Worldwide, wetlands have often been destroyed to make room for farmland or cities [2]. In the San Francisco Estuary, over 90\% of wetlands have been lost in the past 150 years (Figure 2). Some of those wetlands were turned into farmland by the building of walls of dirt (called levees) to keep the water out. Some wetlands have been converted to duck-hunting clubs, which are still wetlands but are walled off from the rivers, so fish cannot move in and out. Around San Francisco Bay, some former tidal wetlands are used to harvest the salt left behind by evaporating ocean water, and others have been filled in to build neighborhoods and towns. Even the tidal wetlands that still exist are in trouble. These wetlands remove pollution from the water, but pollution can hurt the wetland in the process. Many species from other places have become "invaders," especially in the San Francisco Estuary. The invasive species either take over the space (like water weeds), hog all the food (like invasive clams), or even eat the native fish (like the invasive Largemouth Bass) [3, 4]! In the future, sea-level rise caused by global warming may flood the wetlands, making the water too deep for the plants that grow there.

All these problems for tidal wetlands mean problems for fish, too. The numbers of native fish in the San Francisco Estuary have decreased over the past 20 years, and wetland loss may be partially to blame [2]. Many fish in the estuary do not have enough to eat, but scientists find fish with full bellies close to tidal wetlands [3]. Young salmon traveling through the San Francisco Estuary are also in danger of getting eaten by bigger fish. Tidal wetlands provide places to rest and hide. Loss of tidal wetlands could mean the death of more salmon before they reach the ocean. 


\section{Figure 2}

Most of the tidal wetlands in the San Francisco Estuary have been destroyed or changed to use for other purposes, such as building or farming. Green hatched areas show tidal wetlands in the early 1800 s vs. the 2000s.

\section{RESTORATION}

Actions to make an area that was previously changed by humans work in a more natural way to help animals and plants.

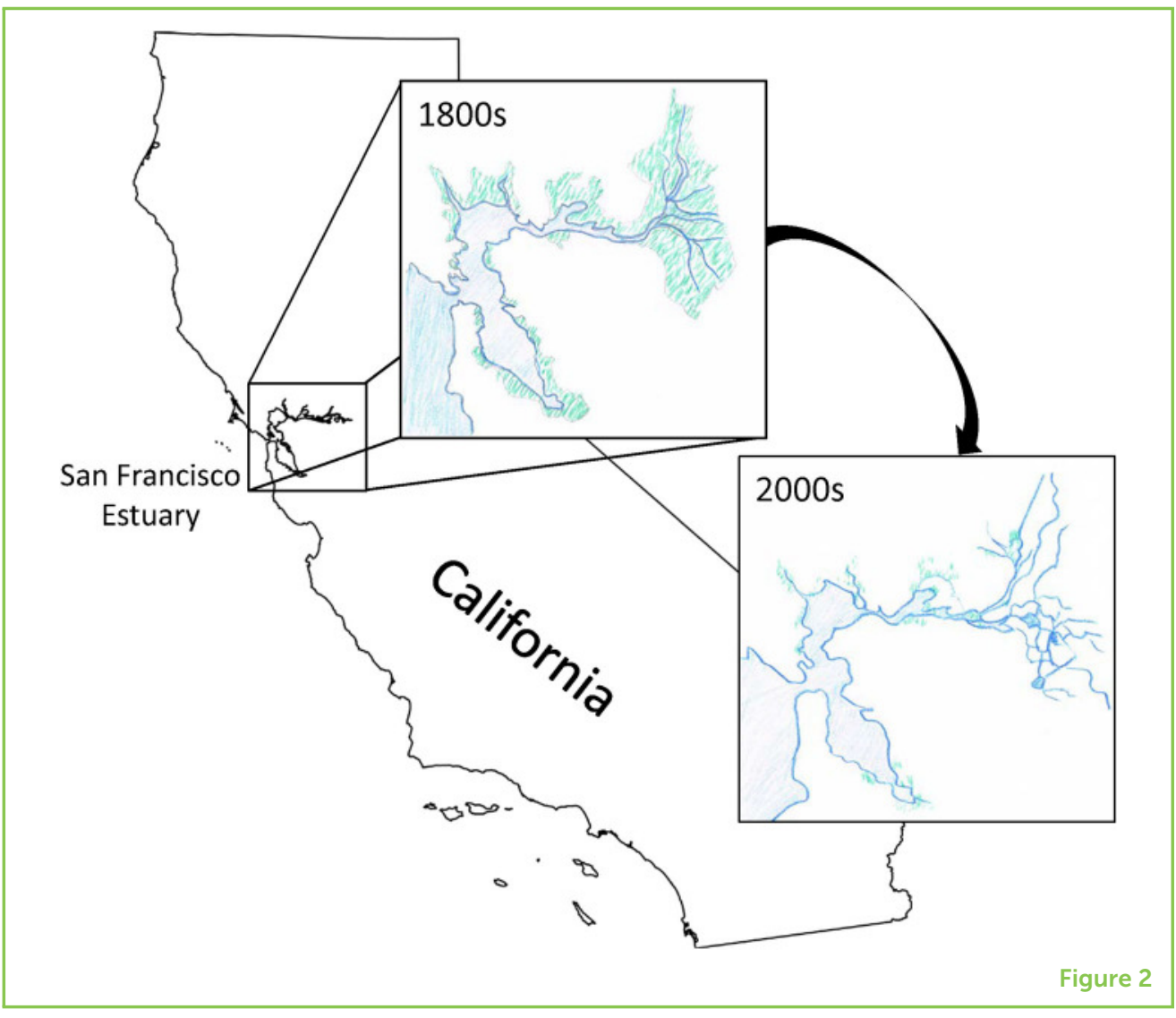

\section{TIDAL WETLAND RESTORATION}

Fortunately, people now realize how important tidal wetlands are for both fish and people, so we are starting to restore some of the wetlands we have lost. Tidal wetland restoration often involves using bulldozers and heavy machinery to knock down levees and dredge new channels to reconnect dried-out land to the rivers, allowing wetlands to form [1]. Invasive plants are removed and native water-loving plants are added to restore the natural community. Once the plants and the landscape have been restored, fish and invertebrates will find the new wetland and make it their home (Figure 3).

We cannot restore all the wetlands we have lost. In some places, the land is no longer the right depth to be covered and uncovered by the changing tides, so native aquatic plants will not grow there [1]. Also, restoring wetlands is expensive, and restoration can sometimes harm other species that live in the area [4]. Moving enough dirt to restore the natural ecosystem is a lot of work and disturbs all the plants and animals living in the area during the construction!

Because tidal wetland restoration is such a big investment, we want to be sure restored wetlands provide a good home for fish and other wildlife. Therefore, after restoration, we take measurements of plants, invertebrates, fish, water quality, and landscape change for many years, to make sure the restored area is working the same as the original 


\section{Figure 3}

(A) Before restoration dry land is separated from tidal waters by structures like levees. (B) Construction is performed to remove levees and invasive plants, and native plants may be added. (C) Restoration can create a functioning tidal wetland, in which native species can thrive.

A Before

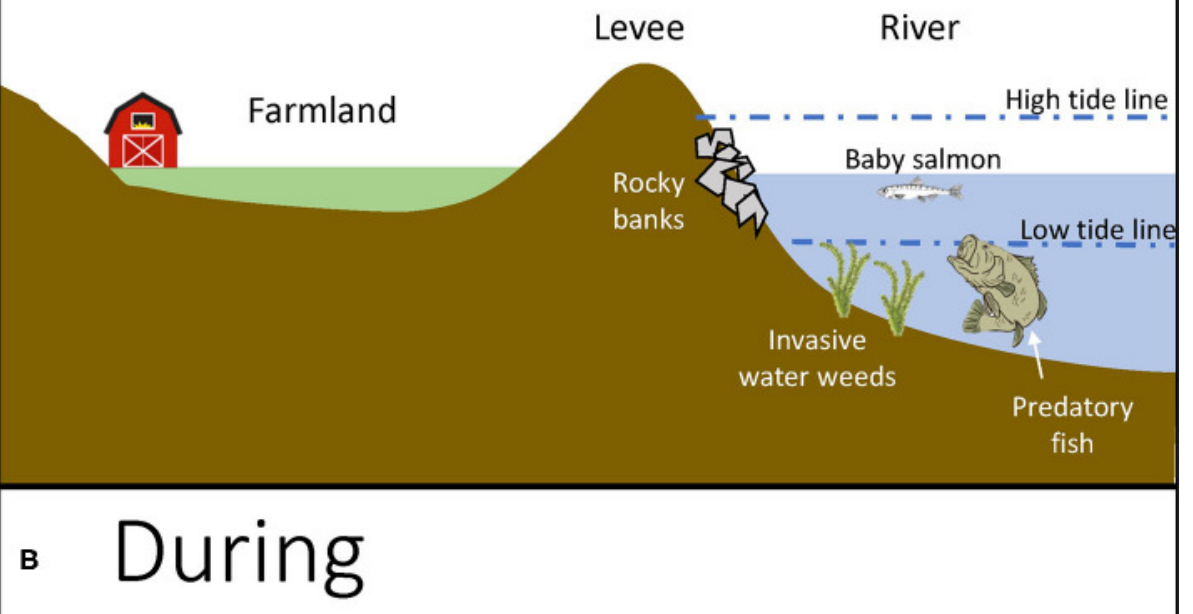

Restoration Project

River

Plant native

vegetation

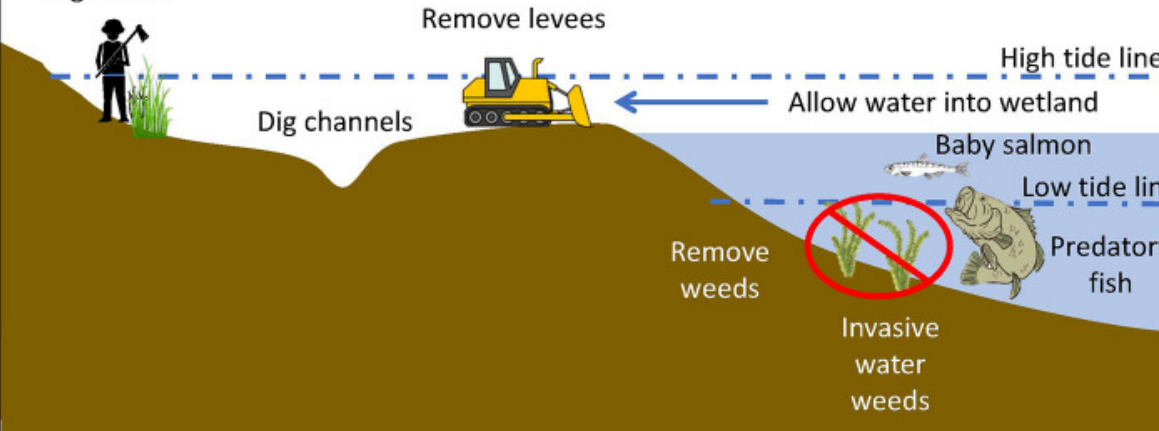

C

After

Tidal Wetland

River

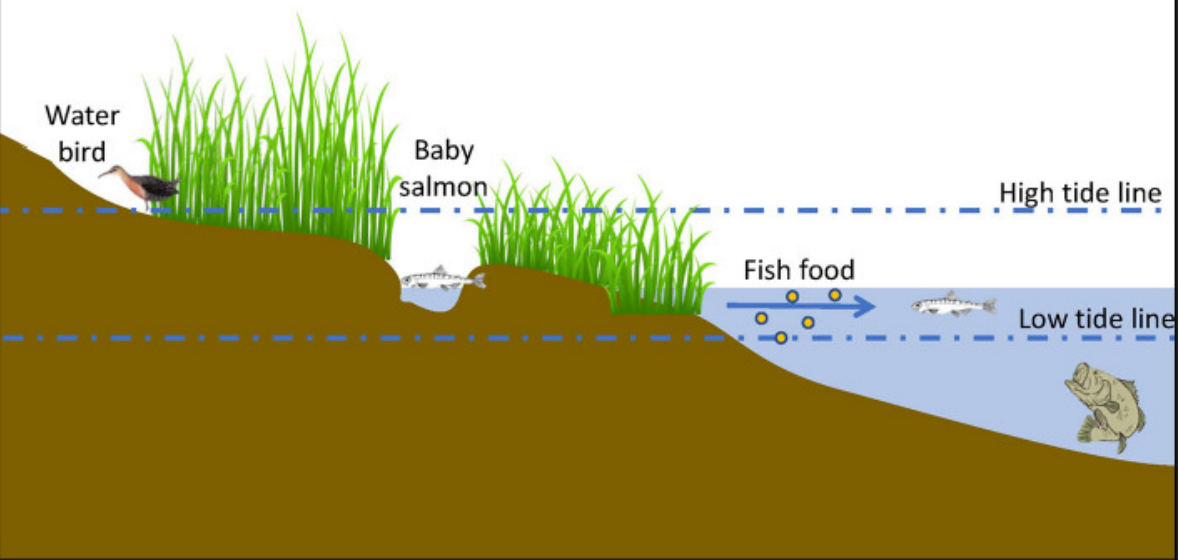

Figure 3 
ADAPTIVE

MANAGEMENT

Taking an action (like restoration), watching to see what works (or does not work), and learning to make future actions better.

1 https://www yolobasin.org /virtualwetl andtours/, https://www. elkhornslough org/story/, https:// oceanconservancy. org/blog/2020 /05/14/experienceamericaswetlands-home/

2 Worldwetlandsday.org wetland. If the tides cannot come in and out properly, if the native plants won't grow, if there are few invertebrates present, or if the fish do not find it, we know we did not restore the wetland properly. In that case, we might make additional changes, such as putting in new channels, filling in other channels, taking out more invasive plants, or putting in new plants. We use our scientific monitoring to guide these changes and we also learn from our experiences, so that we can make future restoration better-that's what we call adaptive management [4].

We have already seen evidence that restoration helps fish, both in the San Francisco Estuary and in other, similar estuaries. Tidal wetland restoration in Puget Sound (Washington State) has made homes for lots of young salmon, and they are now bigger and healthier when they reach the ocean than they were before restoration [5]. Some fish that look for food near tidal wetlands in the San Francisco Estuary find more invertebrates than do fish that try to find food in river channels [3]. It's like the wetlands are a series of rest-stops, with restaurants and motels for the traveling fish!

\section{WHAT CAN YOU DO TO HELP PROTECT WETLANDS?}

There are some simple things that you can do every day to help protect wetlands and their benefits for fish and people!

First, be an Earth Hero! Take care of the environment right where you are. Believe it or not, substances like chemicals, plastics, and even soapy water that get into storm drains can pollute the waterways that lead to wetlands. If you have an aquarium, never release the animals or plants into the wild-they might just end up as the next invasive species!

Now that you know how important tidal wetlands are, you can also get to know and love a wetland near you! If you live near or visit the San Francisco Estuary, the Yolo Bypass Wildlife Area, Elkhorn Slough Wildlife Area, and Rush Ranch are just a few of the places where people can safely get up close and personal with wetlands. If you do not live near a tidal wetland, you can still experience how beautiful and full of life they are by visiting websites that describe these areas ${ }^{1}$. You can also help to celebrate wetlands everywhere on World Wetlands Day, February 2 each year ${ }^{2}$ !

Finally, keep learning about tidal wetlands and tell your friends and family about what you have learned. We need more people to understand and appreciate these important areas. Who knows, someday you might even become the next great wetlands scientist! 


\section{ACKNOWLEDGMENTS}

We are grateful for the efforts of the Fish Restoration Program to restore valuable wetlands and for the many scientists who work to monitor and learn from restoration! Special thanks to Peggy Lehman for leading the San Francisco Estuary collection and Karen Gerhts for commenting on the manuscript.

\section{REFERENCES}

1. Zedler, J. B., and Kercher, S. 2005. Wetland resources: status, trends, ecosystem services, and restorability. Annu. Rev. Environ. Resourc. 30:39-74. doi: 10.1146/annurev.energy.30.050504.144248

2. Sherman, S., Hartman, R., and Contreras, D., editors. 2017. Effects of Tidal Wetland Restoration on Fish: A Suite of Conceptual Models. Sacramento, CA: Department of Water Resources.

3. Hammock, B. G., Hartman, R., Slater, S. B., Hennessy A., and Teh, S. J. 2019. Tidal wetlands associated with foraging success of delta smelt. Estuaries Coasts 42:857-67. doi: 10.1007/s12237-019-00521-5

4. Nagarkar, M., and Raulund-Rasmussen, K. 2016. An appraisal of adaptive management planning and implementation in ecological restoration case studies from the San Francisco Bay Delta, USA. Ecol. Soc. 21:43. doi: 10.5751/ES-08521-210243

5. Woo, I., Davis, M. J., Ellings, C. S., Hodgson, S., Takekawa, J. Y., Nakai, G., et al. 2019. A mosaic of estuarine habitat types with prey resources from multiple environmental strata supports a diversified foraging portfolio for Juvenile Chinook Salmon. Estuaries Coasts 42:1938-54. doi: 10.1007/s122 37-019-00613-2

SUBMITTED: 17 September 2020; ACCEPTED: 19 July 2021; PUBLISHED ONLINE: 16 August 2021.

EDITED BY: Theodore M. Flynn, California Department of Water Resources, United States

CITATION: Sherman S and Hartman R (2021) Marsh Madness: Restoring Tidal Wetlands in Our Estuaries. Front. Young Minds 9:607674. doi: 10.3389/frym.2021. 607674

CONFLICT OF INTEREST: The authors declare that the research was conducted in the absence of any commercial or financial relationships that could be construed as a potential conflict of interest.

COPYRIGHT (c) 2021 Sherman and Hartman. This is an open-access article distributed under the terms of the Creative Commons Attribution License (CC BY). The use, distribution or reproduction in other forums is permitted, provided the original author(s) and the copyright owner(s) are credited and that the original publication in this journal is cited, in accordance with accepted academic practice. No use, distribution or reproduction is permitted which does not comply with these terms. 


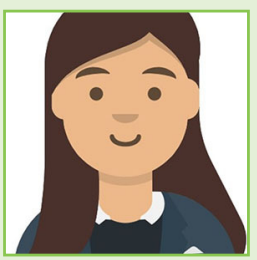

\section{YOUNG REVIEWER}

\section{ANUSHA, AGE: 9}

I am a 9-year-old girl and I am in 3rd grade. I love to read books, especially fantasy and science-fiction. I have finished reading the Harry Potter, Percy Jackson, Magic Tree House, The Time Machine, and The Lord of The Rings series. I want to be part of this review process because I want to continue to learn and help other kids to learn by volunteering as reviewer.

\section{AUTHORS}
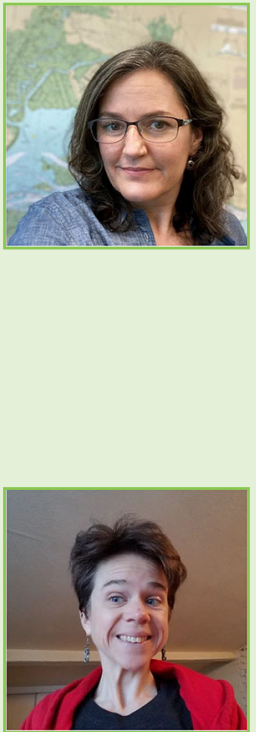

\section{STACY SHERMAN}

My team at the California Department of Fish and Wildlife studies how restored tidal wetlands in the San Francisco Estuary benefit native fish. We provide data to help people improve future restoration projects. As a Cajun, I grew up in Louisiana, among wetlands, on the water, and eating amazing seafood. I feel very lucky to have a career learning about and protecting special ecosystems. Outside of work I enjoy building/sewing/painting things, riding my bike, and spending time with my family, which includes two cute and goofy rescue mutts: Hazel and Lucy. *stacy.sherman@awildlife.ca.gov

\section{ROSEMARY HARTMAN}

My job involves taking information from all the monitoring programs around the region and using it to answer big questions, like "How can we save native fish?" I work on many different topics, but wetlands are special to me because I used to be on the monitoring team for wetland restoration in the Delta. I have worked in wetlands all over the country-including the Everglades, the marshes of Wisconsin, the mountain meadows of the Rockies, and the mangrove swamps of the Florida panhandle. In my spare time, I love hiking, biking, birding, and exploring the outdoors of California. 